\title{
Geotrichum silvicola sp. nov., a novel asexual arthroconidial yeast species related to the genus Galactomyces
}

Correspondence

Carlos A. Rosa

carlrosa@icb.ufmg.br

\author{
Raphael S. Pimenta, ${ }^{1}$ Priscila D. D. Alves, ${ }^{1}$ Ary Corrêa Jr, ${ }^{1}$ \\ Marc-André Lachance, ${ }^{2}$ G. S. Prasad, $^{3}$ Rajaram, $^{4}$ B. R. R. P. Sinha ${ }^{5}$ \\ and Carlos A. Rosa ${ }^{1}$ \\ ${ }^{1}$ Departamento de Microbiologia - ICB, C.P. 486, Universidade Federal de Minas Gerais, \\ Belo Horizonte, MG, 31270-901, Brazil \\ ${ }^{2}$ Department of Biology, University of Western Ontario, London, Ontario, Canada N6A 5B7 \\ ${ }^{3}$ Microbial Type Culture Collection and Gene Bank (MTCC), Institute of Microbial \\ Technology (IMTECH), Council of Scientific and Industrial Research (CSIR), \\ Sector-39A, Chandigarh - 160 036, India \\ ${ }^{4}$ Central Tasar Research and Training Institute, Research Extension Centre, \\ Palampur - 176 061, India \\ ${ }^{5}$ Central Tasar Research and Training Institute, Ranchi, India
}

Four strains of an asexual arthroconidial yeast species were isolated from Drosophila flies in two Atlantic rain forest sites in Brazil and two strains from oak tasar silkworm larvae (Antheraea proylei) in India. Analysis of the sequences of the D1/D2 large subunit rRNA gene showed that this yeast represented a novel species of the genus Geotrichum, described as Geotrichum silvicola sp. nov. The novel species was related to the ascogenous genus Galactomyces. The closest relatives of Geotrichum silvicola were Galactomyces sp. strain NRRL Y-6418 and Galactomyces geotrichum. The type culture of Geotrichum silvicola is UFMG-354-2 ${ }^{\top}\left(=\mathrm{CBS} 9194^{\top}=\mathrm{NRRL}\right.$ $\left.\mathrm{Y}-27641^{\top}\right)$.
Yeasts from the arthroconidial ascomycetous genus Geotrichum Link: Fries represent the anamorphic state of species of the genera Dipodascus Lagerheim and Galactomyces Redhead \& Malloch (Kurtzman \& Robnett, 1998; Ueda-Nishimura \& Mikata, 2000). The genus Geotrichum has 11 species of which five have their teleomorph in the genus Dipodascus and two in the genus Galactomyces. Four Geotrichum species have no known sexual state (de Hoog et al., 1998).

During a survey of yeasts associated with flies of the genus Drosophila in the Atlantic rain forest of Brazil, we isolated four strains of a yeast identified as Geotrichum sp. Three strains were isolated from the gut and one from external surfaces of the flies. In another study of yeast communities associated with insects, two strains also identified as

Published online ahead of print on 13 August 2004 as DOI 10.1099/ ijs.0.63187-0.

\section{Abbreviation: LSU, large subunit.}

The GenBank/EMBL/DDBJ accession number for the large subunit rRNA gene sequence of strain UFMG-354- ${ }^{\top}$ is AY158042 and of strain MTCC 3974 is AY225313.
Geotrichum sp. were isolated from oak tasar silkworm larvae (Antheraea proylei) in India. The sequence of the D1/D2 domains of the large subunit (LSU) rRNA gene of a Brazilian strain and an Indian strain showed that they represented the same species, related to the genus Galactomyces. The closest relative of this novel species was a strain designated by Kurtzman \& Robnett (1998) as Galactomyces sp. NRRL Y-6418. The D1/D2 domain of the LSU rRNA gene of this novel species differed by 15 substitutions from that of Galactomyces sp. NRRL Y-6418. In this report, we describe the novel species Geotrichum silvicola sp. nov.

\section{Isolation and characterization of yeasts}

The strains considered in this study are listed in Table 1 . The Brazilian strains were collected in 2000 and 2001 in two Atlantic rain forest sites in the state of Minas Gerais, Brazil. One site was localized in the Parque Estadual do Rio Doce, while the other was the Ecological Station of the Universidade Federal de Minas Gerais. Drosophila species specimens were captured directly from the surface of decaying fruits using sterile plastic bags. Adult flies were allowed to walk on YM agar ( $1 \%$ glucose, $0.5 \%$ peptone, 
Table 1. Sources of isolation of Geotrichum silvicola

\begin{tabular}{|lll|}
\hline Locality & \multicolumn{1}{c|}{ Strain no. ${ }^{*}$} & \multicolumn{1}{c|}{ Origin } \\
\hline $\begin{array}{l}\text { UFMG Ecological } \\
\text { Station }\end{array}$ & UFMG-DC13-2 & Surface of Drosophila \\
& & \\
& UFMG-DC49-5 & Gut of Drosophila \\
Parque Estadual & UFMG-DC71.1 & Gut of Drosophila \\
do Rio Doce & UFMG-354-2 & Gut of Drosophila \\
India & MTCC 3974 & Silkworm larva \\
& MTCC 6224 & Silkworm larva \\
\hline
\end{tabular}

*UFMG, Universidade Federal de Minas Gerais, Brazil; MTCC, Microbial Type Culture Collection and Gene Bank, India.

$0 \cdot 3 \%$ malt extract, $0 \cdot 3 \%$ yeast extract, $2 \%$ agar, supplemented with $100 \mathrm{mg}$ chloramphenicol $\mathrm{l}^{-1}$ ) for $\mathrm{l}-2 \mathrm{~h}$ before being removed and identified. Yeasts from these plates were predominantly carried on the external surfaces and should include as minor components cells regurgitated by the flies, cells present in faecal pellets and cells carried on the ovipositor of females. Another set of adult flies was surfacesterilized in the field by immersion in $70 \%$ ethanol for $1 \mathrm{~min}$ and transported to the laboratory within $2 \mathrm{~h}$ in tubes containing sterile water on ice. These flies were directly streaked on to YM agar (Morais et al., 1995). Plates were incubated at room temperature $\left(25 \pm 3{ }^{\circ} \mathrm{C}\right)$. The plates were examined periodically and representative yeast colonies were purified and maintained on YM slants or in liquid nitrogen. Two strains from India were isolated from cocoons of dead larvae of Antheraea proylei. These larvae feed on leaves of the kharsu oak (Quercus semecarpifolia) and abound in the rainy season (June-July). Strain MTCC 3974 was isolated in February 2002 and strain MTCC 6224 was recovered in July 2002, from Joginder Nagar, Himachal Pradesh, India, at an altitude of $2500 \mathrm{~m}$. The relative humidity was $90-100 \%$ at the time of collection. The larvae are normally infected in the 4th or 5th stage. Although cocoon formation may occur, extensive infection causes pupae to dissolve completely. The dissolved contents of larvae were streaked on YM agar. Yeasts were characterized by standard methods (Yarrow, 1998). Identities were verified using the keys of Kurtzman \& Fell (1998) and also using the program YEASTCOMPARE (Ciriello \& Lachance, 2001), which compares the nutritional characteristics of any yeast with those of known species.

\section{DNA sequence and PCR analysis}

The D1/D2 divergent domains of the LSU rRNA gene were amplified by PCR from whole cells as described previously (Lachance et al., 1999). The amplified DNA was concentrated and cleaned on QIAquick PCR columns (Qiagen) and sequenced in an ABI sequencer at the John P. Robarts Research Institute (London, Ontario, Canada). Sequences were edited with the program DNAMAN, version
4.15 (Lynnon BioSoft). Existing sequences for other species were retrieved from GenBank. The CLUSTAL W (Thompson et al., 1994) algorithm provided in the DNAMAN package was used to align the sequences and construct a neighbourjoining tree with 1000 bootstrap iterations.

Geotrichum silvicola strains UFMG-354-2 ${ }^{\mathrm{T}}$, UFMG-DC13-2, UFMG-DC49-5, UFMG-DC71.1 and MTCC 3974 were used for PCR fingerprinting. Yeast DNA was purified as described by Pataro et al. (2000). The primer EI1 (5'CTGGCTTGGTGTATGT-3'; de Barros Lopes et al., 1998) targets intron-splicing sites in mutatable regions of the Saccharomyces genome. Each PCR assay was performed in a $10 \mu \mathrm{l}$ reaction mixture containing $1 \mu \mathrm{l}$ DNA, $1 \mu \mathrm{l} 10 \mu \mathrm{M}$ EI1 primer, $1 \mu \mathrm{l} 10 \times$ PCR buffer, $0.5 \mu \mathrm{l}$ dNTPs $(2.5 \mathrm{mM}$ each) and $0 \cdot 3 \mu \mathrm{l} \mathrm{Taq}$ DNA polymerase $\left(5 \mathrm{U}^{-1} \mathrm{l}^{-1}\right)$. Samples were overlaid with $10 \mu \mathrm{l}$ mineral oil prior to PCR amplification. PCR conditions were $5 \mathrm{~min}$ at $95^{\circ} \mathrm{C}$ and two cycles of $30^{\circ} \mathrm{C}$ for $2 \mathrm{~min}$, extension at $72^{\circ} \mathrm{C}$ for $30 \mathrm{~s}$ and denaturation at $95^{\circ} \mathrm{C}$ for $30 \mathrm{~s}$. This was followed by 32 cycles with an annealing temperature of $40{ }^{\circ} \mathrm{C}$ for $2 \mathrm{~min}$, extension at $72{ }^{\circ} \mathrm{C}$ for $30 \mathrm{~s}$ and denaturation at $95^{\circ} \mathrm{C}$ for $30 \mathrm{~s}$. A last cycle of annealing for $2 \mathrm{~min}$ at $40^{\circ} \mathrm{C}$ and extension for $5 \mathrm{~min}$ at $72^{\circ} \mathrm{C}$ was added. The PCR products were analysed by gel electrophoresis on $6 \%$ acrylamide. The gel was stained with silver nitrate and scanned.

\section{Classification and ecology}

Strains UFMG-354-2 ${ }^{\mathrm{T}}$ and MTCC 3974 differed by only three substitutions in the D1/D2 region of the LSU rRNA gene, indicating that they were closely related. PCR amplification with the intron-splicing-site primer gave similar, but not identical, profiles in the five strains of Geotrichum silvicola examined (Fig. 1). Strain MTCC 3974, in particular, lacked one, or possibly two, bands in the 298-344 base range. Isolates from the same species generally give similar PCR profiles (de Barros Lopes et al., 1998). The small amount of polymorphism observed here was consistent with the variation observed between conspecific strains of different origins, as for example in strains of Saccharomyces cerevisiae, Metschnikowia pulcherrima, Dekkera bruxellensis, Dekkera anomala and Hanseniaspora uvarum (de Barros Lopes et al., 1998; Guerra et al., 2001). The novel species belonged to a clade of several Galactomyces species (Fig. 2). Some controversy exists as to the delimitation of Galactomyces and Dipodascus. Kurtzman \& Robnett (1998) suggested that there is no basis for maintaining two separate genera, as the two are phylogenetically intertwined. Naumova et al. (2001) argued differently. As ascospore formation has not been observed in Geotrichum silvicola, the species was assigned to the anamorph genus Geotrichum, independently of the eventual resolution of conflicting views on the nomenclature of its closest relatives. These include an undescribed species named Galactomyces sp. NRRL Y-6418 by Kurtzman \& Robnett (1998). The latter differs from Geotrichum silvicola by 15 substitutions in the D1/D2 region of the LSU rRNA gene. 


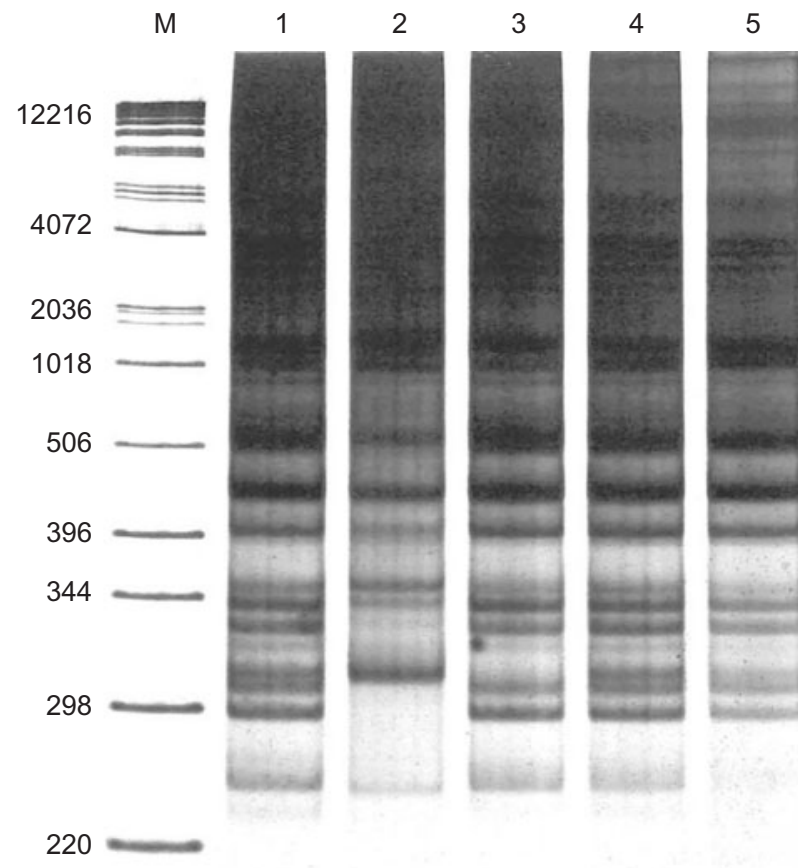

Fig. 1. $P C R$ fingerprints of Geotrichum silvicola strains obtained using the primer El1. Lanes: $M, 1 \mathrm{~kb}$ ladder; 1, UFMG-354-2 ${ }^{\top}$; 2, MTCC 3974; 3, UFMG-DC13-2; 4, UFMGDC71.1; 5, UFMG-DC49-5.

Three isolates of Geotrichum silvicola from the UFMG Ecological Station were obtained from Drosophila specimens feeding on fruits of Acrocomia aculeata (Arecacae). The strain isolated in the Ecological Reserve of the Parque Florestal do Rio Doce was obtained from the gut of a fly feeding on an unidentified decaying fruit on the ground. These results suggested that Geotrichum silvicola may be part of the yeast community associated with this and other tropical fruits. The yeast may participate in the microbial deterioration of fruits in these forest environments. That three of the four strains of Geotrichum silvicola were isolated

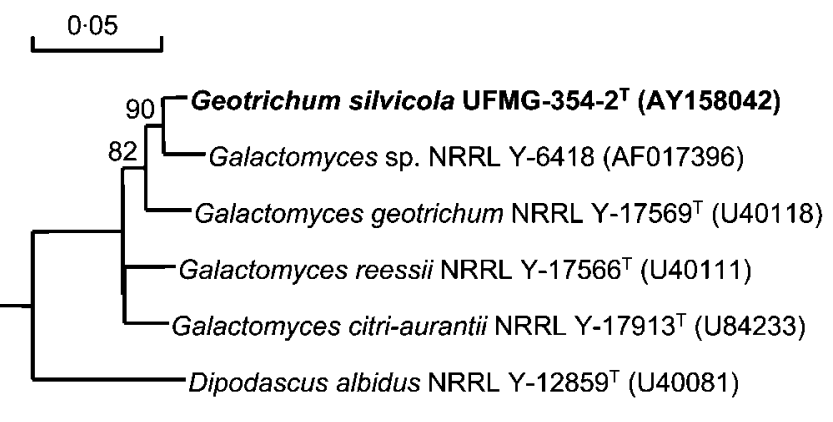

Fig. 2. Neighbour-joining phylogram based on the D1/D2 divergent domains of the LSU rRNA gene of Geotrichum silvicola and its closest relatives. The percentage bootstrap values were obtained from 1000 iterations. Bar, 5\% sequence divergence. from the guts of the flies suggested that the yeast is consumed as food by the flies. Yeasts are known to be a source of food for Drosophila and the flies are important vectors for these micro-organisms (Starmer, 1981; Morais et al., 1994). The Indian strains were isolated from the cocoons of dead larvae of Antheraea proylei, which originate from a cross between the two species Antheraea roylei (from the Himalayan valley) and Antheraea pernyi (from China). These larva feed on leaves of $Q$. semecarpifolia. The isolation of two strains from larvae in different months suggested that the yeast may have a role in the infection of larvae. However, as some other filamentous fungi were also isolated from the infected larvae, the exact role of the yeast species remains to be established.

\section{Identification}

Physiologically similar, most species in the Galactomyces clade utilize few carbon compounds. Most species of the genus assimilate glucose, galactose, L-sorbose, D-xylose, ethanol, glycerol, D-mannitol, D-glucitol, DL-lactate, succinate and citrate as carbon source. Geotrichum silvicola can be separated from Galactomyces reessii by the utilization of D-mannitol, which does not occur in the latter. Galactomyces citri-aurantii utilizes ribitol, but Geotrichum silvicola does not. Physiological separation of Geotrichum silvicola and Galactomyces geotrichum is more difficult. Galactomyces geotrichum gives variable responses for growth on D-ribose, ribitol, D-mannitol, DL-lactate, succinate and citrate, as well as for the fermentation of glucose. Growth on D-ribose and ribitol are negative for Geotrichum silvicola and the yeast does not ferment glucose. All six strains of Geotrichum silvicola were able to assimilate D-mannitol, DL-lactate, succinate and citrate. The isolates were examined after growth on the most common sporulation media (5\% malt extract agar, cornmeal agar, yeast carbon/base agar with $0 \cdot 1 \%$ of ammonium sulfate, dilute V8 agar and potato/ dextrose agar), but asci were not found. All isolates were mixed in pairs and no signs of conjugation were observed.

\section{Latin diagnosis of Geotrichum silvicola Pimenta, Prasad, Lachance et Rosa sp. nov.}

Cultura in agaro malti post dies $7\left(22^{\circ} \mathrm{C}\right)$ plana, sicca, capillata et candida. Hyphae ramosae cum arthroconidiis formantur, at non cellulae gemmantes. In agaro farinae Zea mays post dies 14 mycelium verum et arthroconidia formantur. Asci nec ascosporae non formantur. Glucosum non fermentatur. Galactosum, L-sorbosum, D-xylosum, ethanolum, glycerolum, mannitolum, glucitolum, ethyl acetas, D-gluconatum (variabile), acidum lacticum (lente), acidum succinicum et acidum citricum assimilantur, at non maltosum, sucrosum, raffinosum, D-ribosum, inulinum, melibiosum, lactosum, trehalosum, melezitosum, cellobiosum, salicinum, amylum solubile, L-rhamnosum, L-arabinosum, D-arabinosum, methanolum, 2-propanolum, erythritolum, ribitolum, galactitolum, meso-inositolum, 2-keto-gluconatum, glucosaminum, $\mathrm{N}$-acetylglucosaminum, xylitolum, acetonum nec hexadecanum. Lysinum, ethylaminum et cadaverinum 
assimilantur et non natrium nitricum et natrium nitrosum. Ad crescentiuam vitaminae externae non necessariae. Augmentum in $30^{\circ} \mathrm{C}$, at non $37^{\circ} \mathrm{C}$. Habitat Drosophila in Brazil et larvae bombicis Antheraea roylei in India.

Typus UFMG-354-2 $2^{\mathrm{T}}$. In collectione zymotica Centraalbureau voor Schimmelcultures, Trajectum ad Rhenum, sub no. CBS $9194^{\mathrm{T}}$ typus stirps deposita est.

\section{Description of Geotrichum silvicola Pimenta, Prasad, Lachance \& Rosa sp. nov.}

Geotrichum silvicola (sil.vi'co.la. L. nom. masc. n. silvicola inhabiting woods).

After 7 days on malt extract/yeast extract agar at $22^{\circ} \mathrm{C}$, colonies are white, flat, dry and powdery to finely hairy. Budding cells are absent. Hyphae are 6-7 $\mu \mathrm{m}$ wide, with frequent dichotomous branching at the apex, with early disarticulation into cubic arthroconidia. Arthroconidia are hyaline and slightly inflating to 5-6 $\mu \mathrm{m}$ wide and $30-55 \mu \mathrm{m}$ long. A pellicle is formed after 2 days on fermentation medium. In Dalmau plates after 2 weeks on cornmeal agar, abundant true mycelia and arthroconidia are formed (Fig. 3). Glucose is not fermented. Assimilation of carbon
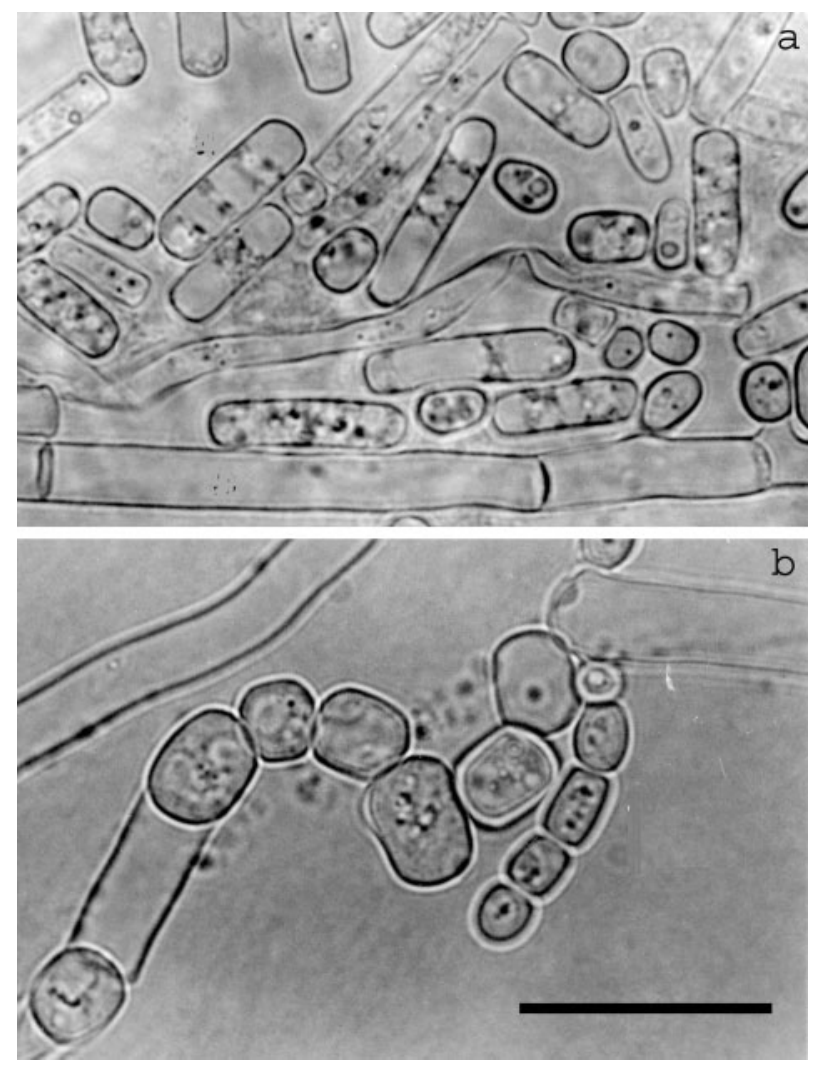

Fig. 3. Phase-contrast micrographs of Geotrichum silvicola after 2 weeks on cornmeal agar at $25^{\circ} \mathrm{C}$. (a) Vegetative cells, true hyphae and arthrospores; (b) arthrospore formation after 1 day on yeast extract/malt extract agar. Bar, $5 \mu \mathrm{m}$. compounds: galactose, L-sorbose, D-xylose, ethanol, glycerol, D-mannitol, D-glucitol, lactic acid (weak), succinic acid, citric acid, D-gluconate (variable) and ethyl acetate. No growth occurs on maltose, sucrose, raffinose, D-ribose, cellobiose, lactose, melibiose, melezitose, inulin, starch, trehalose, L-arabinose, D-arabinose, L-rhamnose, erythritol, ribitol, galactitol, salicin, myo-inositol, methanol, hexadecane, glucosamine, xylitol, acetone, 2-propanol or $\mathrm{N}$ acetylglucosamine. Assimilation of nitrogen compounds: positive for lysine, ethylamine $/ \mathrm{HCl}$ and cadaverine; negative for nitrate and nitrite. Growth in vitamin-free medium is positive. Growth in amino acid-free medium is positive. Growth at $30^{\circ} \mathrm{C}$ is positive, but at $37^{\circ} \mathrm{C}$ is negative. Growth on YM agar with $10 \%$ sodium chloride is negative. Growth in $50 \%$ glucose/yeast extract $(0.5 \%)$ is negative. Starch-like compounds are not produced. Growth on $1 \%$ acetic acid medium is negative. In 100 and $1000 \mu \mathrm{g}$ cycloheximide $\mathrm{ml}^{-1}$, growth is positive. Urease activity is negative. Diazonium Blue B reaction is negative. The habitat is Drosophila flies in the Atlantic rain forest and possibly fruits visited by the flies in Brazil and larva of the oak tasar silkworm, Antheraea proylei, in India.

The type strain is UFMG-354-2 ${ }^{\mathrm{T}}$, isolated from the gut of a Drosophila fly in Parque Estadual do Rio Doce in State of Minas Gerais, Brazil. It has been deposited in the collection of the Yeast Division of the Centraalbureau voor Schimmelcultures, Utrecht, the Netherlands, as strain CBS $9194^{\mathrm{T}}\left(=\mathrm{NRRL} \mathrm{Y}-27641^{\mathrm{T}}\right)$.

\section{Acknowledgements}

This work was funded by the Conselho Nacional de Desenvolvimento Científico e Tecnológico of Brazil (Programa de Pesquisas Ecológicas de Longa Duração - PELD/CNPq/UFMG - site 04, CNPq - PADCT process no. 62.0477/98-9 and $\mathrm{CNPq}$ - process no. 477528/03-1), Fundação ao Amparo a Pesquisa de Minas Gerais (FAPEMIG process no. CBB 1207/98), by the Natural Science and Engineering Research Council of Canada (M.-A. L.) and by the Department of Biotechnology, Government of India and Council of Scientific and Industrial Research (G.S.P.). We acknowledge the cooperation of Gabriel M. F. Almeida, Luiz H. Rosa and Marcelo F. G. Brito during the sample collection and G.S. P. acknowledges the technical assistance of Mr Paramjit.

\section{References}

Ciriello, C. J. \& Lachance, M. A. (2001). YEASTCOMPARE. University of Western Ontario, London, Canada.

de Barros Lopes, M., Soden, A., Martens, A. L., Henschke, P. A. \& Langridge, P. (1998). Differentiation and species identification of yeasts using PCR. Int J Syst Bacteriol 48, 279-286.

de Hoog, G. S., Smith, M. T. \& Guehó, E. (1998). Dipodascus de Lagerhein. In The Yeasts, a Taxonomic Study, 4th edn, pp. 181-193. Edited by C. P. Kurtzman \& J. W. Fell. Amsterdam: Elsevier.

Guerra, J. B., Araújo, R. A. C., Pataro, C., Franco, G. R., Moreira, E. S. A., Mendonça-Hagler, L. C. \& Rosa, C. A. (2001). Genetic diversity of Saccharomyces cerevisiae strains during the $24 \mathrm{~h}$ fermentative cycle for the production of the artisanal Brasilian cachaça. Lett Appl Microbiol 33, 106-111. 
Kurtzman, C. P. \& Fell, J. W. (1998). The Yeasts, a Taxonomic Study. Amsterdam: Elsevier.

Kurtzman, C. P. \& Robnett, C. J. (1998). Identification and phylogeny of ascomycetous yeasts from analysis of nuclear large subunit (26S) ribosomal DNA partial sequences. Antonie van Leeuwenhoek 73, 331-371.

Lachance, M. A., Bowles, J. M., Starmer, W. T. \& Barker, J. S. F. (1999). Kodamaea kakaduensis and Candida tolerans, two new ascomycetous yeast species from Australian Hibiscus flowers. Can J Microbiol 45, 172-177.

Morais, P. B., Rosa, C. A., Hagler, A. N. \& Mendonça-Hagler, L. C. (1994). Yeast communities of the cactus Pilosocereus arrabidae as resources for larval and adult stages of Drosophila serido. Antonie van Leeuwenhoek 66, 313-317.

Morais, P. B., Rosa, C. A., Hagler, A. N. \& Mendonça-Hagler, L. C. (1995). Yeast as descriptors of habitat use by the Drosophila fasciola subgroup (repleta group) in Atlantic rain forests. Oecologia 104, 45-51.

Naumova, E. S., Smith, M. Th., Boekhout, T., de Hoog, G. S. \& Naumov, G. I. (2001). Molecular differentiation of sibling species in the Galactomyces geotrichum complex. Antonie van Leeuwenhoek 80, 263-273.

Pataro, C., Guerra, J. B., Petrillo-Peixoto, M. L., Mendonça-Hagler, L. C., Linardi, V. R. \& Rosa, C. A. (2000). Yeast communities and genetic polymorphism of Saccharomyces cerevisiae strains associated with artisanal fermentation in Brazil. J Appl Microbiol 89, 24-31.

Starmer, W. T. (1981). A comparison of Drosophila habitats according to the physiological attributes of the associated yeast communities. Evolution 35, 38-52.

Thompson, J. D., Higgins, D. G. \& Gibson, T. J. (1994). CLUSTAL W: improving the sensitivity of progressive multiple sequence alignment through sequence weighting, position-specific gap penalties and weight matrix choice. Nucleic Acids Res 22, 4673-4680.

Ueda-Nishimura, K. \& Mikata, K. (2000). Two distinct $18 \mathrm{~S}$ rDNA secondary structures in Dipodascus (Hemiascomycetes). Microbiology 146, 1045-1051.

Yarrow, D. (1998). Methods for the isolation and identification of yeasts. In The Yeasts, a Taxonomic Study, 4th edn, pp. 77-100. Edited by C. P. Kurtzman \& J. W. Fell. Amsterdam: Elsevier. 